\title{
Institutions and the Legislative Success of 'Strong' Presidents: An Analysis of Government Bills in Chile *
}

\author{
Authors: \\ Eduardo Alemán \\ University of Houston \\ and \\ Patricio Navia \\ New York University
}

\begin{abstract}
This paper examines the approval of government bills in Chile, evaluating the effect of presidential prerogatives and policy substance, and considering both bill-specific and contextual effects. The results show that presidential prerogatives over financial policy as well as the ability to affect the congressional agenda through urgent bill scheduling, significantly influence government bill approval. As expected, government success is enhanced during the honeymoon period. However, changes in public approval of the president do not appear to exert a significant effect on the passage of presidential bills.
\end{abstract}

Forthcoming in the Journal of Legislative Studies

* The authors would like to thank Chris Nicholson, Germana González Navas, and Marina Lacalle for their comments and suggestions. Eduardo Alemán would like to acknowledge the funding received from the Division of Research at the University of Houston to complete part of this study. Patricio Navia acknowledges support from Proyecto Fondecyt 2007-2008: No. 1085243. 
Among scholars of presidentialism, the policy success of governments was once considered to be a consequential factor in the stability of democratic regimes (Linz 1990, Mainwaring 1993, Shugart and Carey1992). Today, questions of policy conflict and interbranch bargaining remain central in presidentialism research. We know considerably more about presidential prerogatives, electoral rules, and party discipline than we did thirty years ago. However, several aspects of the lawmaking process remain unexplored, hindering our understanding of presidential systems outside the United States. The fate of the government's legislative program is one such fundamental and understudied issue.

With the president as the chief proponent of major policy reforms and the effectiveness of governments stemming principally from the approval of executiveinitiated bills, empirical analysis of such proposals reveals crucial aspects of presidential politics. Certain single-nation studies have begun exploring in greater detail those mechanisms that facilitate or obstruct the passage of legislation (Alston and Mueller 2005, Llanos 2001), and some recent works have also presented aggregate data on the approval of such proposals (Cheibub, Przeworski \& Saiegh 2004, Figueiredo and Limongi 2000). But statistical analyses of the success of individual initiatives are rare, hindering our understanding of the various forces systematically influencing the approval of government legislative programs. ${ }^{1}$ This paper contributes to filling this void in the presidentialism literature by examining the success of government proposals in Chile.

The Chilean executive is representative of the institutionally-powerful Latin American president. Chile normally ranks high across most institutional measures of presidential strength, along with other countries such as Argentina, Brazil, Colombia, and Peru. While the formal authority of the Chilean president in the lawmaking process is 
well-documented (Londregan 2000, Siavelis 2000), it has yet to be examined how some of these prerogatives, as well as other contextual and bill-specific variables, affect the approval of government bills. Are prerogatives like scheduling and proposal power actually effective in determining the fate of individual bills? Chilean presidents have enjoyed majorities in the lower chamber of congress, but they lacked a formal partisan majority in the Senate until early 2006. Are institutionally 'strong' presidents influenced by contextual forces like public approval, the electoral calendar, or shifting partisan margins in congress? Answering these questions is important to further our understanding of government bill approval, and Chile represents a crucial case to illuminate lawmaking by powerful presidents.

This paper offers two important contributions with respect to prior studies of legislative politics in presidential nations. First, amid scant comparative analyses of determinants of legislative success, it extends the discussion to a prototypical case of strong presidentialism. Since the overwhelming majority of the literature on presidential legislative success focuses on the U.S., an atypical case concerning formal presidential powers over legislation, extending existing research to legislatively-strong Latin American presidents should improve our understanding of lawmaking under presidentialism. Second, this paper shifts the research focus from those broad forces influencing aggregate bill approval rates to the impact of institutional prerogatives on the fate of individual bills. Arguments concerning presidential performance tend to emphasize the consequences of contextual characteristics such as presidential partisan support or presidential popularity, as opposed to bill-specific effects. In this paper, we assert that institutional prerogatives (over the timing of bills and certain policy domains), as well as constraints (in changes to 
constitutional matters) significantly impact the likelihood of passage for individual bills, even after controlling for contextual forces affecting all bills.

This paper employs an original dataset of presidential bills initiated between the return of democracy in 1990 and 2003 to examine the forces that influence the legislative success of Chilean presidents. The results reveal that presidential bills prioritized by the president through use of urgency motions, and bills falling within presidential policy domains ('money bills' and international agreements) are significantly more likely to pass. In contrast, bills seeking to amend aspects of the constitution met much lower approval odds. In regard to contextual forces, we found no effect for presidential popularity, while uncovering significant effects associated with the electoral cycle and partisan composition of congress.

\section{THE PRESIDENT IN THE LEGISLATIVE ARENA}

Presidents in Latin America are considered to be the chief initiators of important legislative proposals. While the degree to which individual legislators also initiate important bills varies from country to country, a general consensus exists that the key to major policy change lies with the government's legislative program (Cox \& Morgenstern 2001). Unlike U.S. presidents, who must rely on members of congress, all Latin American presidents may directly introduce legislation in a wide variety of policy areas, and are the sole initiators on certain policy matters. Presidents tend to enjoy substantial legislative prerogatives, such as broad budgetary authority and monopoly agenda control during special sessions of congress. Such prerogatives were established across Latin America during the $19^{\text {th }}$ and early $20^{\text {th }}$ centuries. In nations such as Chile, presidents may also present amendments on the floor of congress and dispatch ministers to participate in 
committee deliberations and congressional debates. However, the degree to which this historically vigorous role of Latin American presidents represents a strategy for successful legislative achievements remains unclear.

Presidential success in the legislative arena has been well-researched by U.S. presidential scholars, who portray the process as revealing of various influences such as partisan responsiveness, inter-branch stalemate, presidential popularity, and the electoral calendar (Bond \& Fleisher 1990; Edwards 1989; Covington, Wrighton, \& Kinney 1995). Given the substantive differences found in procedural rules and agenda-setting authority, plus ample variations in the partisan make-up of congress, it is unclear whether findings from the U.S. can be generalized to other presidential democracies.

The legislative politics literature provides two main conceptualizations of presidential success in the legislative arena. One set of studies examines the number of relevant bills enacted during a particular period (congressional session or presidential term). These works focus on government productivity, the ability to move policy away from the status quo. Mayhew (2005, p. 200), who advocates this approach, argues that "in the final analysis, what matters is whether the government actually does something new." In contrast, the second group of studies incorporates both a numerator and denominator into the analysis. The focus here is on government success, or the ability to accomplish an underlying agenda of changes to the status quo. As Binder (2003, p. 35) notes, analyses measuring output without respect for the core policy agenda risk "misstating the true frequency of gridlock.” By focusing on executive-initiated bills and examining the forces affecting approval of such proposals, the approach of this paper falls within the latter group of studies. 
In the following sections, we discuss a series of hypotheses concerning the success of presidential legislation. We expect bills formally prioritized by the executive and those falling within their constitutionally-established policy domains to have a high likelihood of passage. Conversely, we expect bills seeking modifications in areas where partisan minorities hold veto power through formalized higher voting thresholds or quorums, to have comparatively lower odds of success than the typical executive proposal.

\section{GOVERNMENT PRIORITIES}

After sending a given bundle of initiatives to congress, Latin American presidents possess several useful formal prerogatives for influencing the pace at which these bills are examined. One of the most salient is the power to attach a motion of 'urgency' to a particular piece of legislation, accelerating consideration of a bill by altering the congressional agenda. This agenda-setting device is found in the constitutions of Brazil, Chile, Colombia, Ecuador, Paraguay, and Uruguay. It may be employed as both a signaling device and a scheduling tool, prioritizing specific proposals in a busy environment, or in some cases compelling congress to address a legislative initiative. As Morgenstern (2002, p. 438) notes, urgency powers intended to help the president overcome legislative bottlenecks 'can have dramatic effects on executive-legislative relations, legislative organization and the policy process more generally.'

In Chile, formal authority to demand urgent treatment of legislation is established in Article 74 of the 1980 Chilean Constitution. Presidents may utilize three types of urgency motions: an immediate motion imposes a three-day deadline; a suma motion a tenday deadline; and simple motions a thirty-day deadline. Presidents may also withdraw and renew these urgency motions. However, when a vote is ultimately scheduled it may not 
constitute the final passage vote, and in the vast majority of cases it does not. As may be expected, legislators have expressed their disagreement with the use of urgency motions, and some have sought unsuccessfully to change this constitutional provision. Issuance of such motions can be viewed as interference with a chamber's regular timetable, and therefore a challenge to the congressional leadership ordinarily in charge. However, we believe a more appropriate portrayal of presidential urgencies is as a bargaining tool useful for shortening leadership negotiations and compelling legislative decision-making.

Chilean presidents tend to attach simple urgencies to legislation nearly twice as often as the other two urgency varieties, and are more responsive in rescinding or extending such deadlines. Approximately one-fourth of presidential bills are declared at some point or another to be matters of simple urgency. Ordinarily, simple urgency motions appear to signal presidential attention rather than compel a floor vote in a relatively short time period. ${ }^{2}$

Within the narrower set of bills that receive suma or immediate urgency requests, we find the agenda prioritized by the government. Such motions are often employed when timely approval appears threatened by contentious disagreement. They are also utilized to speed along the final touches on proposals that have already been negotiated with leading opposition parties. In either case the executive decides which bills will be negotiated and prioritized for an eventual floor vote, and which ones will be postponed (perhaps indefinitely). As Carlos Carmona, director of the president's Legislative Liaison Office (División Juridico-Legislativa, Minsterio Secretaria General de la Presidencia) notes: 'urgencies are a tool to move forward and signal presidential priorities. When there are 
many bills with urgencies, committees only attend to the one with the highest urgency. In this way the government organizes the agenda. ${ }^{3}$

While the power to introduce urgency motions provides the executive with substantial agenda-setting power, an initial study found no clear association between urgency motions and overall bill passage rates (Siavelis 2000, p. 93). In order to properly capture the effect of urgencies on the likelihood of approval, we must examine more thoroughly the impact of each type of urgency motion while controlling for other factors. This point is addressed in the empirical section of the paper.

\section{POLICY DOMAINS}

A defining characteristic of Latin American presidential systems is the influence of the executive branch over 'money' bills. Presidential power over the purse stems from formal authority granted in the constitution, as well as informal authority gained through policy expertise. Presidents in Brazil, Chile, Colombia, Ecuador, El Salvador, Panama, Peru, and Uruguay are among those possessing substantial authority over taxation and spending legislation. In these nations, budgetary policy is considered an executive domain, with legislators severely constrained in their ability to introduce spending legislation and make amendments with fiscal implications. As such, major economic reforms and their associated legislation originate almost exclusively from the government.

Chilean presidents hold several prerogatives over taxation and spending policy, including sweeping authority over the budget process (Baldez \& Carey 1999; Alesina et al. 1999). Chilean legislators are forbidden to introduce amendments that increase spending or create financial commitments, and every congressional legislative proposal containing fiscal implications must be accompanied by a financial report from the executive’s Budget 
Office estimating the financial impact of the project and sources of financing under current budget law (Aninat et al. 2006). In addition, any new tax or amendment to an existing tax scheme must originate with the executive branch. All proposals bearing fiscal implications must also be referred to the Public Finances (Hacienda) committee, where members of the executive branch are often present to indicate the government's desires and respond to congressional concerns. This forced referral to the Public Finances committee is useful for our empirical examination, granting us a means to distinguish these bills from others on the agenda.

In addition to their significant authority over fiscal legislation, Chilean presidents hold monopoly proposal power regarding international agreements. According to the Chilean constitution (Article 50), these proposals cannot be amended in committee and must be voted on under closed rules. Although little comparative evidence exists on success rates for legislative proposals by policy area, preliminary evidence from Argentina and Costa Rica points to a clear difference between bills related to international agreements and domestic policy legislation (with the former seeing substantively higher aggregate passage rates). ${ }^{4}$ This is consistent with the 'two presidencies' thesis, ${ }^{5}$ which argues that the U.S. Congress defers to the executive branch in areas considered to be of presidential expertise, such as foreign affairs and defense.

While presidents are favored on matters of economic and foreign policy, they often face greater obstacles when attempting to modify certain fundamental, agreed-upon rules. Institutional reform initiatives (e.g., constitutional amendments, changes to organic laws or the electoral system) are among those high-stakes issues likely to generate substantial 
congressional opposition. Furthermore, a number of these initiatives require support from qualified majorities to become law.

Constitutional reform has figured prominently as a public policy issue since Chile re-democratized in 1990. This constitutional debate is linked with the legacy of the authoritarian regime, which crafted the document that has structured Chilean democratic politics since 1990. This remains a contentious issue, dividing the government coalition from the opposition. All Chilean presidents (and legislators from all parties) have introduced bills to modify an aspect of this document in some way. However, the formal requirement that qualified majorities in each chamber endorse constitutional amendments has sharply reduced the range of feasible reforms. During this period, the opposition also believed that departure from the status quo would engender an overwhelming loss, and so generally fought to maintain the institutional design created by the departed military regime.

Other executive initiatives to alter certain basic institutional arrangements are also difficult to enact, but more common than constitutional reform bills. In Chile, such bills are commonly referred to the committee on Constitutional and Judicial Matters (Constitución y Justicia). This committee (each chamber has one) examines institutional reform initiatives concerning the judiciary and state agencies, as well as proposed policy changes in areas such as electoral law, the civil and penal codes, congressional lobbying, regional administrations, and civil rights. These proposals tend to address high-stakes policy matters that sometimes require an absolute (and occasionally a qualified) congressional majority to reach quorum. ${ }^{6}$

\section{CONTEXTUAL EFFECTS}


The prior discussion emphasized the effect of institutional prerogatives and policy substance on individual bills. However, passage of the government's legislative program may also be impacted by effects that are specific to particular periods, and therefore influence groups of bills. The comparative literature has traditionally emphasized such effects on individual bill traits, partly due to the tendency to compare aggregate passage rates across countries.

One of the most common propositions in the comparative study of presidentialism is that government achievements are linked to the president's partisan legislative support (Linz 1990). It seems relatively uncontroversial to expect members of the president's party to provide more reliable support for government bills than other legislators. Several reasons exist to anticipate close links between the president and fellow partisans in congress. ${ }^{7}$ They share similar electoral coalitions, and members of the president's party seeking re-election must usually run on the president's record as well as their own (Bond and Fleisher 1990). In her analysis of significant U.S. presidential legislation, Binder (2003) notes how divided government leads to a (modest) decline in approval rates for the president’s program vis-à-vis unified government. Jones' (1995) comparative analysis of Latin American presidencies also provides some evidence of executive-legislative conflict as a function of presidential party size in the legislature.

But presidents may succeed in the legislative arena despite holding minority status. In the U.S. case, Mayhew (2005) noted that the total number of significant bills passed is relatively unaltered by divided government. In Latin America, not only can presidents recruit fellow partisans and woo others via budget resources or other individually-targeted benefits, they may also utilize their agenda-setting authority to advance their policy 
program. When necessary, compromise may also be employed as means to achieve policy gains. Following the last wave of democratization, several presidents have successfully governed without congressional majorities, and many minority presidents have formed multiparty coalitions. Moreover, recent statistical studies have challenged the link between minority governments and democratic breakdown, indicating that minority governments are not victimized by frequent inter-branch stalemate (Cheibub, Przeworski \& Saiegh 2004).

Another contextual force that tends to influence government bill passage is the electoral cycle. The idea that presidents benefit from a honeymoon with congress early in their terms is common in the presidentialism literature. A newly-inaugurated president not only bears the latest popular mandate, but is also the principal actor in deciding the future distribution of government benefits. The combination of resources that presidents possess early on - their political capital - tends to decline after their first year in office, particularly when the president cannot be immediately re-elected (as in Chile). Some empirical evidence exists for this association, with both Altman (2000) and Morgenstern (2001) pointing out that in Uruguay, defections from presidential coalitions are common as the end of a presidential term approaches. Amorim Neto (2002) also illustrates that the coalition discipline of governing parties in Brazil decreases later in the president's term. Navia and Velasco (2003) emphasize how Chilean president Patricio Aylwin took advantage of his post-inaugural political capital to successfully negotiate tax increases and labor reforms with the conservative opposition. While evidence regarding to the U.S. has been mixed (Lockerbie, Borrelli \& Hedger 1998; Canes-Wrone \& de Marchi 2002), recent works on Colombia, and Paraguay have found the electoral cycle exerts a significant effect 
on the passage of executive-initiated legislation (Cárdenas, Junguito \& Pachón 2006; Molinas, Pérez-Liñan \& Saiegh 2004).

Similarly, government legislative achievements have also been linked to the president's public standing. The effect of presidential popularity on lawmaking has

remained an important research area in U.S. politics for some time, with the overall evidence being mixed, suggesting that the legislative effects of this presumed association to be marginal at best (Bond, Fleisher \& Wood 2003; Canes-Wrone \& de Marchi 2002). While the field of public opinion is well-developed in Latin America, the link between presidential popularity and legislative policy outcomes remains understudied. Calvo (2007), in a paper on Argentina, argues that legislators are responsive to public opinion and presents evidence that approval rates affect the success of executive-initiated bills. However, comparative evidence from other presidential nations remains scarce.

\section{ANALYZING LEGISLATIVE SUCCESS}

The preceding discussion leads to a series of hypotheses regarding government bill approval. The first three refer to bill-specific characteristics, ceteris paribus: (1) bills prioritized by the government should have higher probabilities of success than nonprioritized bills; (2) presidential proposals concerning fiscal matters and international agreements should be more apt to pass than other domestic proposals; and (3) constitutional as well as institutional-reform initiatives should be more likely to fail than other domestic bills. In addition, we have those contextual effects highlighted in the established literature. Accordingly, (4) improvements in the president's public image should translate into higher approval for government bills; (5) greater support for the government in terms of legislative seat share should improve the odds of government bill 
passage; and (6) initiatives introduced during the president's first year in office (honeymoon) should be more likely to pass than those introduced later. ${ }^{8}$

Testing for these effects also requires controlling for other influences. First, we account for the number of legislative proposals introduced during a congressional period. The total number of bills comprising the government's legislative program tends to vary over time and between presidents. While some presidents may come to power with ambitious agendas reflected in numerous legislative initiatives, others advance a more modest program, perhaps concentrating on a few crucial reforms. Given the time constraints endemic to all national legislatures, the sheer volume of introduced proposals may create bottlenecks that depress the number of bills actually reported from committee and addressed by the plenary. When programs address substantial reforms that demand active presidential involvement and bargaining with congress, presidents may be well advised to focus on a few particular bills. For example, Rivers and Rose (1985, pp. 19293) found that presidential agenda size to be negatively associated with legislative approval, and argue that in the U.S. 'presidents behave strategically in setting the size of their programs.'

We also introduce control variables to capture the effects of multiple committee referrals, as well as no committee referral. In a setting characterized by time constraints, forced referral to several committees adds obstacles that can put proposals at a disadvantage. Some evidence exists that multiple committee referrals in the U.S. Congress fuels obstruction (Davidson, Oleszek \& Kephart 1988; Young 1996). Multiple policy issues increase the complexity of proposals, and the attention of numerous interest groups can delay resolution. In contrast, a very small group of bills travel to enactment with 
astounding speed, circumventing the committee process. Such proposals are usually negotiated in advance between the government and opposition, with the avoidance of committee referral agreed on by congressional actors. Consequently, it is reasonable to control for these unusual initiatives that likely have strong chances for passage.

In Chile, nearly one-third of executive proposals are assigned to multiple committees. During the period under study, a bill referred to more than one Senate committee likely faced at least one opposition-dominated committee. While congressional committees in Latin America are certainly weaker than their U.S. counterparts, Chile’s congressional committees are considered rather muscular. For instance, in a recent study by the Inter-American Development Bank (2006) classifying the strength of congressional committees in eighteen Latin American countries, Chile’s committees were ranked in the top category ("high”) with five other nations. Although Chilean committees tend to be populated by legislators with long congressional tenures, frequent changes in positions of authority (chairs and vice-chairs) and alterations in committee assignments contribute to undermine their autonomy.

Finally, we introduce controls to account for labor, education, and public works legislation. These policy areas are commonly associated with center-left coalitions, and represent matters publicly highlighted by all Chilean presidents.

\section{DATA AND MODEL}

For our empirical analysis, we collected a variety of information on each bill introduced by Chilean presidents from the return to democracy in 1990 until March $2006{ }^{9}$ This period encompasses the entire terms of three presidents: Patricio Aylwin (1990-1994); Eduardo Frei Ruiz-Tagle (1994-2000); and Ricardo Lagos (2000-2006). During this time, 
presidents introduced a total of 1,701 bills (Mensajes legislativos), of which 1,113 were domestic initiatives and the rest international agreements (Acuerdos).

The number of bills introduced by presidents in each congressional period varies over time. President Alwyn, who governed during the first four years, adopted an ambitious agenda at a time when numerous changes to the status quo were sought by members of the government coalition. In the first years following democratization, legislators introduced relatively few bills, whereas Aylwin was pressured to fulfill his various campaign promises made at the end of military rule. President Frei also introduced a high number of initiatives early in his administration, followed by a noticeable decrease in the mid 1990s, coinciding with an international financial crisis and loss of support at home. President Lagos followed a different path, starting out with a modest number of initiatives in the first two years (his most difficult time in office), and increasing the number of initiatives to a higher level in the last four years (as his public standing rose).

Figure 1 presents the total number of government initiatives introduced in each congressional period, as well as the approval rate of domestic and foreign policy initiatives. Presidents succeeded in passing some three-fourths of their domestic proposals sent to congress. During the presidency of Eduardo Frei, we observe the highest approval rates with fewer government bills overall. In terms of total bills passed, Patricio Aylwin has the largest share with 491 proposals approved during his four years in office.

[Figure 1, about here]

The statistical model employed to test our previously-discussed hypotheses is a two-level random intercept model. This model has a dichotomous dependent variable $\gamma_{i j}$ indicating whether executive bill $i$ belonging to congressional period $j$ was approved by 
both chambers. The probability of success $\pi_{i j}=P\left(\gamma_{i j}=1\right)$ was modeled using a logit function.

Two reasons exist for selecting this approach: first, our data follows a multilevel structure with the unit of analysis being individual bills (level-1) grouped by congressional period (level-2). Employing an ordinary logistic regression with this type of panel data would violate the independence of errors assumption, and the results (e.g., standard errors) would be unreliable. A random effects model can account for this lack of independence in the grouped data, with groups identified as samples from a population of groups, and group-dependent intercepts considered as random. ${ }^{10}$ An alternative approach that also accounts for group dependence in the data is the so-called fixed-effects model. An important difference is that such an approach considers each group as possessing its own systematic baseline, meaning that intercepts are fixed.

Second, we are interested in assessing the effects of certain contextual variables with similar values for all proposals within each congressional period and varying only across periods, such as partisan support for the president. While a random effects model permits inclusion of group-level predictors, a fixed effects model cannot, as these predictors would be perfectly collinear with the baseline level for each group. Four of the five models presented in the next section are random effects models that include group predictors.

The independent variables utilized are measured in the following manner: a series of dummy variables indicate whether a bill received any type of urgency request from the president; whether it falls within the jurisdiction of the Public Finances, Constitutional, Education, Labor, or Public Works committees; whether it was sent to multiple (or no) 
committees; whether it was introduced in the Senate (where presidents never held a majority); and whether it is an international agreement or a constitutional reform. In addition, we include an indicator of presidential public approval. ${ }^{11}$ We also employ four group-level variables, with two measuring the margin of seats for the presidential coalition (in the Senate and Chamber of Deputies). In addition, we utilize a dummy variable indicating a president's first year in office (honeymoon), and the log of the total number of domestic laws proposed by the president per congressional period. We have access to the complete record of proposals until March 2006, but our statistical analysis excludes those proposals introduced during the last two congressional periods to guard against potential right censoring problems. ${ }^{12}$

\section{RESULTS}

Table 1 presents the statistical results for five alternative models. ${ }^{13}$ The first model displayed does not include group-level predictors, while the second, third, and fourth models include one each. As the variable measuring presidential public approval is highly correlated with both honeymoon and number of proposals, we exclude it from the last two models. For the first model, we also ran a fixed-effects model (not shown) and found almost identical results. $^{14}$

\section{[Table 1 about here]}

Independent variables are listed in the first column of Table 1, with related coefficients shown in the same row. The standard errors appear in parentheses just below the coefficients. Below the independent variables we find the estimated standard deviation at the group level $\left(\hat{\sigma}_{j}\right){ }^{15}$ Farther below, we denote two measures of goodness of fit, the 
Akaike information criterion (AIC) and the deviance, which can be used to compare the different models. In both cases, lower values indicate a better fit to the data. Finally, the two rows at the bottom of the table display the number of observations and groups (i.e., congressional periods).

Overall, the results presented in Table 1 are consistent with the first three hypotheses. In terms of governmental prioritization, bills that receive immediate and suma urgency motions appear significantly more likely to pass. These findings confirm the hypothesized effect of presidential prioritization, indicating that different types of urgencies have substantively different effects on legislation. In regards to bills whose content falls within the policy domains of the president - those with fiscal implications or international agreements - the results show their likelihood of passage to be significantly higher than for non-financial domestic bills. In matters where the president is formally constrained, the results were mixed. While constitutional reforms are significantly less likely to pass, other types of bills falling within the jurisdiction of the constitutional committee are not. The coefficients associated with these three hypotheses are statistically significant in all five models.

For instance, the probability of passage for a non-financial domestic bill rises from $60 \%$ without an urgency motion to $73 \%$ with suma urgency, and a remarkable $86 \%$ with an immediate one. ${ }^{16}$ However, bills receiving a simple urgency do not appear more likely to pass than non-urgent proposals - the coefficient is negative and lacks statistical significance. Government bills with fiscal implications (all sent to the Public Finances committee) and international agreements also exhibit high probabilities of success (around 87\% and 86\% respectively). Chances of enactment for presidential bills seeking 
constitutional reform are significantly less promising than for other bills, with two-thirds failing to pass.

The positive image of the president, as measured in public opinion polls, does not appear to influence the likelihood of passage (hypothesis 4). The other variables measuring contextual forces - partisan support and honeymoon - are group predictors (invariant within congressional periods). Given the moderate number of second-level groups, conclusions concerning the effects of these group predictors should be considered preliminary findings.

The coefficient for the 'honeymoon' effect is positive and statistically significant (models \#4 and \#5). The predicted probability of passage for a typical domestic proposal introduced during a president's first year in office is almost 11 percentage points higher than one put forward later in the president's term. This finding confirms the idea that the political climate enjoyed during their first year provides particular advantages for presidents. Regarding partisan support in congress, the results illustrate that margins in the Chamber of Deputies are positively associated with greater likelihood of success, while margins in the Senate proved statistically insignificant.

The impact of changing levels of partisan presidential support can be observed in Figure 2, which plots the likelihood of success for fiscal and other domestic bills given different partisan margins in the lower chamber. ${ }^{17}$ The solid lines chart predicted probabilities, while the dashed lines mark the 90\% confidence interval. As this figure indicates, an increase in seat share in the lower chamber has a marked impact on the odds of approval.

[Figure 2 about here] 
The control variables reveal interesting results as well. Executive bills assigned to more than one committee are no more likely to become law than proposals assigned to a single committee, while the few bills that the plenary choose to take up without a committee referral are significantly more likely to become law. Bills voted on directly by the plenary tend to be important agreements brokered by the president with leaders of congressional political parties, and few such cases exist. For example, prior to the 2001 parliamentary election, a technical mistake in the candidate registration process led to new bill to extend registration deadlines for congressional candidates. This bill was not referred to committee but approved directly by both chambers in two days. While the fact that multiple referrals do not influence the passage of presidential bills might be interpreted as a signal of weak committee influence with regards to the timing of such bills, this finding should not be seen as an indication that Chilean committees are ineffectual at influencing the final content of presidential bills or that interest groups do not see congressional committees as a useful venue for furthering or protecting their interests.

The variable capturing bills referred to the Education committee also exhibits significant results. Presidential bills on this topic are more likely to pass than those in other non-financial domestic areas, with chances of approval being about 15 percentage points higher. Finally, we find a significant effect associated with the size of the president's agenda (Model \#5). This is a second-level variable that loses significance if either the honeymoon variable or the variable representing partisan margins in the lower chamber is excluded. Even with these caveats in mind, the results still suggest that sending too many bills to congress decreases bill approval rates. 
In sum, the results of the statistical analysis lend support to the theory that institutional prerogatives significantly impact the fate of individual bills. Bills prioritized by the president via urgency motions and bills falling within presidential policy domains ("money bills" and international agreements) are more likely to be enacted than others. In turn, presidential bills seeking to amend aspects of the constitution faced much lower chances of approval.

The analysis also confirms the impact of certain contextual variables commonly highlighted in the literature. The favorable context experienced by presidents during the honeymoon period is also found in Paraguay (Molinas, Pérez-Liñan \& Saiegh 2004), Colombia (Cárdenas, Junguito \& Pachón 2006), and the U.S. (Rivers and Rose 1985; Lockerbie et al. 1998). Analysis of the Chilean case reveals the strength of this association vis-à-vis the formal powers of the executive branch: even "strong" presidents tend to lose their legislative effectiveness after their first year in office.

The results also lend some support to the idea that partisan support levels in congress influence the fate of legislation. In the Chilean case, this is a tentative finding that should be reassessed as time passes and additional data is collected and incorporated reflecting various levels of partisan support.

Before concluding, we briefly comment on three of our negative findings. Unlike results from studies of the U.S. and Argentina, our results provide no evidence of associations between the popularity of Chilean presidents and congressional approval of government initiatives. We believe the reasons for this to be electoral: limits on presidential reelection, and incentives influencing congressional candidates to diverge from the median voter in their district (i.e., supporting a popular president is not very important 
to legislators' re-election plans) ${ }^{18}$ In addition, the proliferation of "safe" electoral districts and the presence of non-elected members in the Senate likely make legislators less responsive to fluctuations in public evaluations of the president.

One puzzling finding concerns the lack of an effect for "simple” urgencies. We believe part of the explanation for this lies in executive miscalculations and congressional animosity. Early in the past decade, an overabundance of simple urgency motions were introduced, exacerbating the time constraints of a rather short congressional calendar and fomenting congressional opposition to presidential urgencies. ${ }^{19}$ This overuse of urgencies, according to Carlos Carmona, had the effect of diluting their effectiveness. ${ }^{20}$

Our finding that the probability of success for bills introduced in the oppositiondominated Senate is not lower than for bills introduced in the Chamber of Deputies deserves a final comment. Typically, presidents choose the chamber of origin for their bills, and in most cases (79\%) they chose to give the politically friendlier Chamber of Deputies the first try. However, it is likely that a moderate share of presidential bills, either due to being generally consensual or touching on issues where the Senate is positioned closer to the president, would face a similar path regardless of chamber of origin. These results paint a picture of presidents who skillfully avoid sending a greater share of confrontational bills to the Senate.

\section{CONCLUSION}

This paper explores the forces influencing the success of presidential legislative initiatives in Chile. We find evidence that presidential prerogatives matter for legislative output, with economic initiatives and prioritized proposals seeing higher probabilities of approval than other bills. The notable success Chilean presidents have enjoyed in passing 
'money' bills contrasts with the process typically found in the U.S. model of presidentialism, where such bills cannot be introduced or amended by the president and their content is left entirely to congress. In addition, we point out that positional differences also matter. In high-stakes issues where the opposition possesses incentives to block change and the government coalition must work for unity and cross-coalition ties, such as constitutional reforms, the executive faces greater hurdles and success rates are substantially lower. This occurs despite the formal strength of the Chilean president. We found no evidence linking public approval of the president to changes in success rates for executive-initiated legislation, and we theorize that the ban on immediate presidential reelection and electoral competition dynamics may explain this finding

Our results also reveal the importance of bill-specific characteristics to the likelihood of passage. In Chile, these differences appear to powerfully impact bill approval. Scholars examining legislative outcomes in comparative perspective should note that commonly-emphasized contextual variables tell only part of the story, and individuallevel information may greatly increase explanatory power.

Regarding the study of legislative politics and bill approval in Chile, this area remains open for inquiry, and important questions linger concerning the relative strength of the president. For example, qualitative studies of the passage of major presidential bills may illuminate the extent to which members of congress amend such bills with substantive policy changes, while investigations of cabinet decision-making could delineate the influence of different coalition parties on the formation of the executive's legislative agenda. In addition, statistical studies of legislative success focusing on bills initiated by 
members of congress may assess the extent to which public presidential support is decisive for approval.

In conclusion, understanding the forces influencing approval of the government's legislative program permits better evaluation of the workings of presidentialism. We contribute to this effort by empirically testing a series of hypotheses concerning the legislative success of the institutionally-strong Chilean president. Further analyses of government initiatives in other presidential nations could enhance our assessment of the impact of bill-specific characteristics and allow us to begin describing some systematic patterns across countries. The greater availability of data now seen in many legislatures across the developing world should make this task simpler and easier. 
Figure 1

\section{Government Bills in Chile, 1990-2005}

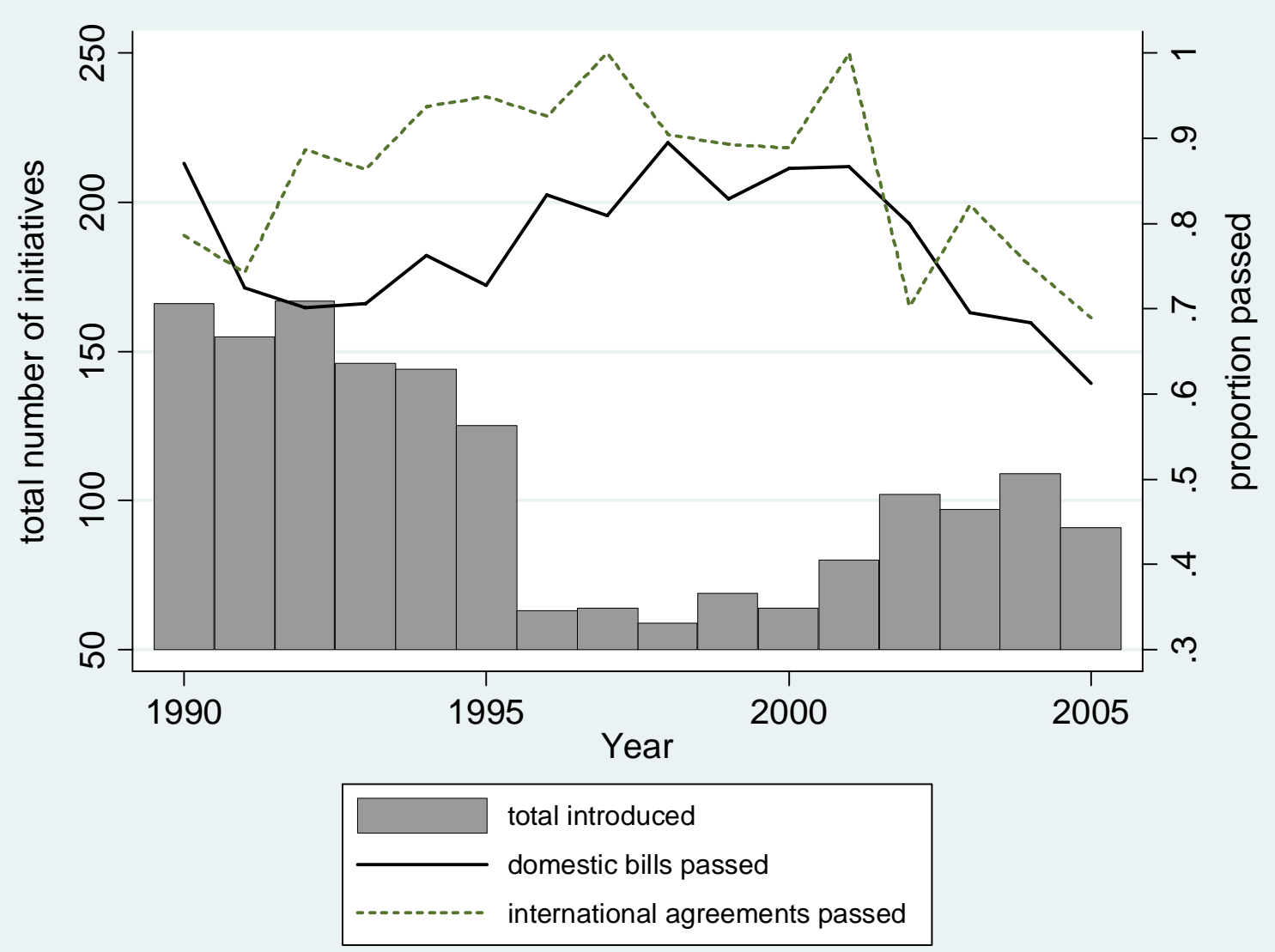


Table 1

Approval of Government Bills in Chile, 1990-2003 ${ }^{a}$

\begin{tabular}{|c|c|c|c|c|c|}
\hline Independent Variables & model \# 1 & model \# 2 & model \# 3 & model \# 4 & model \# 5 \\
\hline Immediate Urgency & $\begin{array}{l}1.388 \text { *** } \\
(0.351)\end{array}$ & $\begin{array}{l}1.388 \text { *** } \\
(0.351)\end{array}$ & $\begin{array}{l}1.417^{* \star *} \\
(0.351)\end{array}$ & $\begin{array}{l}1.389 \star \star \star \\
(0.349)\end{array}$ & $\begin{array}{l}1.348 \text { *** } \\
(0.351)\end{array}$ \\
\hline Suma Urgency & $\begin{array}{l}0.568 \text { *** } \\
(0.216)\end{array}$ & $\begin{array}{l}0.568 \text { *** } \\
(0.216)\end{array}$ & $\begin{array}{l}0.605 \text { *** } \\
(0.217)\end{array}$ & $\begin{array}{l}0.585 \text { *** } \\
(0.214)\end{array}$ & $\begin{array}{l}0.554 \text { ** } \\
(0.217)\end{array}$ \\
\hline Simple Urgency & $\begin{array}{l}-0.162 \\
(0.174)\end{array}$ & $\begin{array}{l}-0.162 \\
(0.175)\end{array}$ & $\begin{array}{l}-0.146 \\
(0.175)\end{array}$ & $\begin{array}{l}-0.150 \\
(0.174)\end{array}$ & $\begin{array}{l}-0.152 \\
(0.175)\end{array}$ \\
\hline International Agreement & $\begin{array}{l}1.402 \text { *** } \\
(0.194)\end{array}$ & $\begin{array}{l}1.402 \text { *** } \\
(0.194)\end{array}$ & $\begin{array}{l}1.407 \text { *** } \\
(0.194)\end{array}$ & $\begin{array}{l}1.415 \text { *** } \\
(0.192)\end{array}$ & $\begin{array}{l}1.359 \text { *** } \\
(0.193)\end{array}$ \\
\hline Constitutional Reform & $\begin{array}{l}-1.147 * \star \star \\
(0.428)\end{array}$ & $\begin{array}{l}-1.147 * * * \\
(0.428)\end{array}$ & $\begin{array}{l}-1.130 \text { *** } \\
(0.428)\end{array}$ & $\begin{array}{l}-1.140 * * * \\
(0.426)\end{array}$ & $\begin{array}{l}-1.212 \text { *** } \\
(0.428)\end{array}$ \\
\hline Constitutional Committee & $\begin{array}{l}-0.214 \\
(0.200)\end{array}$ & $\begin{array}{l}-0.214 \\
(0.200)\end{array}$ & $\begin{array}{l}-0.230 \\
(0.201)\end{array}$ & $\begin{array}{l}-0.206 \\
(0.200)\end{array}$ & $\begin{array}{l}-0.194 \\
(0.200)\end{array}$ \\
\hline Public Finances & $\begin{array}{l}1.492 \text { *** } \\
(0.215)\end{array}$ & $\begin{array}{l}1.492 \text { *** } \\
(0.215)\end{array}$ & $\begin{array}{l}1.470 \text { *** } \\
(0.215)\end{array}$ & $\begin{array}{l}1.500 \text { *** } \\
(0.215)\end{array}$ & $\begin{array}{l}1.478 \text { *** } \\
(0.214)\end{array}$ \\
\hline Education & $\begin{array}{l}0.675 \text { * } \\
(0.373)\end{array}$ & $\begin{array}{l}0.675 \text { * } \\
(0.373)\end{array}$ & $\begin{array}{l}0.714 \text { * } \\
(0.375)\end{array}$ & $\begin{array}{l}0.676 \text { * } \\
(0.372)\end{array}$ & $\begin{array}{l}0.740 \text { ** } \\
(0.375)\end{array}$ \\
\hline Labor & $\begin{array}{r}0.286 \\
(0.307)\end{array}$ & $\begin{array}{r}0.286 \\
(0.307)\end{array}$ & $\begin{array}{r}0.293 \\
(0.308)\end{array}$ & $\begin{array}{r}0.290 \\
(0.306)\end{array}$ & $\begin{array}{r}0.292 \\
(0.308)\end{array}$ \\
\hline Public Works & $\begin{array}{r}0.563 \\
(0.345)\end{array}$ & $\begin{array}{r}0.563 \\
(0.345)\end{array}$ & $\begin{array}{r}0.526 \\
(0.346)\end{array}$ & $\begin{array}{r}0.531 \\
(0.345)\end{array}$ & $\begin{array}{r}0.523 \\
(0.344)\end{array}$ \\
\hline Multiple Committees & $\begin{array}{l}-0.292 \\
(0.213)\end{array}$ & $\begin{array}{l}-0.292 \\
(0.213)\end{array}$ & $\begin{array}{l}-0.297 \\
(0.213)\end{array}$ & $\begin{array}{l}-0.292 \\
(0.213)\end{array}$ & $\begin{array}{l}-0.317 \\
(0.213)\end{array}$ \\
\hline Not Referred to Committee & $\begin{array}{l}0.990 \text { *** } \\
(0.384)\end{array}$ & $\begin{array}{l}0.990 \text { ** } \\
(0.384)\end{array}$ & $\begin{array}{l}0.951 \text { ** } \\
(0.384)\end{array}$ & $\begin{array}{l}0.952 \text { *** } \\
(0.380)\end{array}$ & $\begin{array}{l}1.021 \text { *** } \\
(0.380)\end{array}$ \\
\hline Introduced in Senate & $\begin{array}{r}0.026 \\
(0.177)\end{array}$ & $\begin{array}{r}0.026 \\
(0.177)\end{array}$ & $\begin{array}{r}0.009 \\
(0.176)\end{array}$ & $\begin{array}{r}0.026 \\
(0.176)\end{array}$ & $\begin{array}{r}0.032 \\
(0.175)\end{array}$ \\
\hline Public Approval of President & $\begin{array}{l}-0.001 \\
(0.011)\end{array}$ & $\begin{array}{l}-0.001 \\
(0.012)\end{array}$ & $\begin{array}{l}-0.004 \\
(0.010)\end{array}$ & $\sim$ & $\sim$ \\
\hline Seat Margin in Senate & $\sim$ & $\begin{array}{r}0.001 \\
(0.099)\end{array}$ & $\sim$ & $\sim$ & $\sim$ \\
\hline Seat Margin in Chamber & & $\sim$ & $\begin{array}{l}0.043 \text { ** } \\
(0.017)\end{array}$ & $\sim$ & $\begin{array}{l}0.036 \text { *** } \\
(0.013)\end{array}$ \\
\hline Honeymoon & $\sim$ & $\sim$ & $\sim$ & $\begin{array}{l}0.461 \text { * } \\
(0.241)\end{array}$ & $\begin{array}{l}0.503 \text { *** } \\
(0.183)\end{array}$ \\
\hline In Agenda Size & $\sim$ & $\sim$ & $\sim$ & $\sim$ & $\begin{array}{l}-0.552 \text { *** } \\
(0.199)\end{array}$ \\
\hline Constant & $\begin{array}{r}0.503 \\
(0.586)\end{array}$ & $\begin{array}{r}0.503 \\
(0.589)\end{array}$ & $\begin{array}{l}-0.172 \\
(0.588)\end{array}$ & $\begin{array}{l}0.300 * \\
(0.181)\end{array}$ & $\begin{array}{l}2.015 \text { ** } \\
(0.896)\end{array}$ \\
\hline Group-level standard deviation & 0.327 & 0.328 & 0.241 & 0.234 & 0.000 \\
\hline AIC & 1296.41 & 1298.41 & 1293.08 & 1293.47 & 1285.11 \\
\hline Deviance & 1264.41 & 1264.41 & 1259.08 & 1261.47 & 1249.11 \\
\hline Number of observations & 1501 & 1501 & 1501 & 1501 & 1501 \\
\hline Groups (congressional periods) & 14 & 14 & 14 & 14 & 14 \\
\hline
\end{tabular}

a. All models are random-effects with a logit link. 
Figure 2

\section{The Success of Government Bills in Chile}

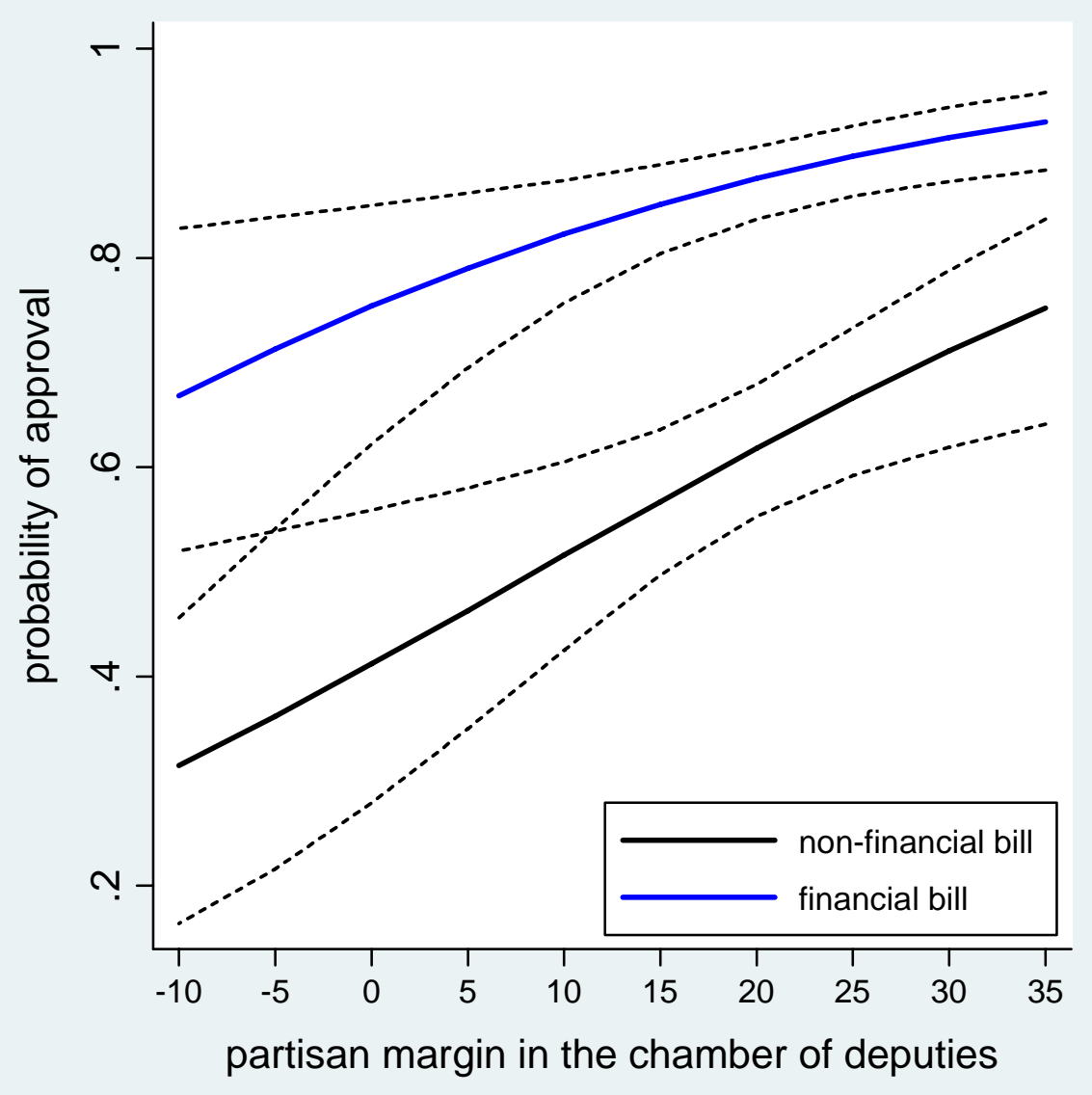




\section{References}

Alemán, E. \& Saiegh, S.M. (2007) Legislative Preferences, Political Parties and Coalition Unity in Chile, Comparative Politics, 39(3), pp. 253-272.

Alesina, A., Hausmann, R., Hommes, R. \& Stein, E. (1999) Budget Institutions and Fiscal Performance in Latin America, Inter-American Development Bank, Office of the Chief Economist Working Paper Series \#34, (Washington D.C.).

Alston, L. J. \& Mueller, B. (2005) Pork for Policy: Executive and Legislative Exchange in Brazil, The Journal of Law, Economics, and Organization, 22(1), pp. 87-114.

Altman, D. (2000) The Politics of Coalition Formation and Survival in Multi-party Presidential Democracies - The Case of Uruguay, 1989-1999, Party Politics 6(3), pp. 259-283.

Amorin Neto, O. (2002) Presidential Cabinets, Electoral Cycles, and Coalition Discipline in Brazil,' in Legislative Politics in Latin America, in: S. Morgenstern B. Nacif (eds.) Legislative Politics in Latin America, pp. pp. 48-78, (New York: Cambridge University Press).

Aninat, C., Londregan, J.B., Navia, P. \& Vial, J. (2006) Political Institutions, Policymaking Processes, and Policy Outcomes in Chile,’ Inter-American Development Bank, Latin American Research Network. Working Paper R-521, (Washington D.C.).

Baldez, L. \& Carey, J.M. (1999) Presidential agenda control and spending policy: Lessons from general Pinochet's constitution, American Journal of Political Science 43(1), pp. 29-55.

Binder, S. A. 2003. Stalemate: Causes and Consequences of Legislative Gridlock (Washington, D.C.: Brookings Institution).

Bond, J.R. \& Fleisher, R. (1990) The President in the Legislative Arena, (Chicago: University of Chicago Press).

Bond, J.R., Fleisher, R. \& Wood, B.D. (2003) The Marginal and Time-Varying Effects of Public Approval on Presidential Success in Congress, Journal of Politics, 65(1), pp. 92-110. 
Calvo, E. 2007. The Responsive Legislature: Public Opinion and Law Making in a Highly Disciplined Legislature, British Journal of Political Science, 37(2), pp. 263-280.

Canes-Wrone, B. \& de Marchi, S. (2002) Presidential Approval and Legislative Success, Journal of Politics 64(2), pp. 491-509.

Cárdenas, M., Junguito R. \& Pachón, M. (2006) Political Institutions and Policy Outcomes in Colombia: The Effects of the 1991 Constitution, Inter-American Development Bank, Latin American Research Network, Working Paper R-508, (Washington D.C.).

Carey, J. M. (2002) Parties, Coalitions, and the Chilean Congress in the 1990s, in: S. Morgenstern B. Nacif (eds.) Legislative Politics in Latin America, pp. 222-253, (New York: Cambridge University Press).

Cheibub, J.A., Przeworski, A. \& Saiegh, S. M. (2004) Government Coalitions and Legislative Success Under Presidentialism and Parliamentarism, British Journal of Political Science, 34(4), pp. 656-587.

Covington, C.R., Wrighton, J.M. \& Kinney, R. (1995) A Presidency-Augmented Model of Presidential Success in Roll Call Votes, American Journal of Political Science, 39(4), pp.1001-1024.

Cox, G.W. \& Morgenstern, S. (2001) Latin America’s Reactive Assemblies and Proactive Presidents,' Comparative Political Studies, 33(2), pp. 171-189.

Davidson, R., Oleszek, W.J. \& Kephart, T. (1988) One Bill, Many Committees: Multiple Referrals in the U. S. House of Representatives, Legislative Studies Quarterly, 13(1), pp. 3-28.

Edwards III, G.C. (1989) At the Margins: Presidential Leadership of Congress (New Haven: Yale University Press).

Figueiredo, A. C. \& Limongi, F. (2000) Presidential Power, Legislative Organization, and Party Behavior in Brazil, Comparative Politics, 32(2), pp. 151-170. 
Jones, M.P. (1995) Electoral Laws and the Survival of Presidential Democracies, (South Bend, IN: University of Notre Dame Press).

Linz, J. (1990) The Perils of Presidentialism, Journal of Democracy, 1(1), pp. 51-69.

Llanos, M. (2001) Understanding Presidential Power in Argentina: a Study of the Policy of Privatisation in the 1990s, Journal of Latin American Studies, 33(1), pp. 67-99.

Lockerbie, B., Borrelli, S. \& Hedger, S. (1998) An Integrative Approach to Modeling Presidential Success in Congress,' Political Research Quarterly, 51(1), pp.155-172.

Londregan, J.B. (2000) Legislative Institutions and Ideology in Chile, (New York: Cambridge University Press).

Magar, E. Marc Rosenblum, M. \& Samuels, D. (1998) On the absence of centripetal incentives in double-member districts - The case of Chile, Comparative Political Studies, 31(6), pp. 714-739.

Mainwaring S. (1993) Presidentialism, Multipartism, and Democracy: The Difficult Combination, Comparative Political Studies, 26(2), pp. 198-228.

Mayhew, D. (2005) Divided We Govern: Party Control, Lawmaking, and Investigations, 19462002, p.200, (New Haven: Yale University Press).

Molinas, J., Pérez-Liñan, A. \& Saiegh, S. M. (2004) Political institutions, policymaking processes, and policy outcomes in Paraguay, 1954-. 2003, Revista de Ciencia Política, 24(2), pp. 67-93.

Molinelli, G., Palanza, V. \& Sin, G. (1999) Congreso, Presidencia y Justicia en Argentina. Materiales para su estudio (Buenos Aires: CEDI/Fundación Gobierno y Sociedad).

Morgenstern, S. (2001) Organized Factions and Disorganized Parties, Party Politics 7(2), pp. 235-256. 
Morgenstern, S. (2002) Explaining Legislative Politics in Latin America, in: S. Morgenstern B. Nacif (eds.) Legislative Politics in Latin America, pp. 413-445, (New York: Cambridge University Press).

Navia P. \& Velasco, A. (2003) The Politics of Second Generation Reforms in Latin America, in: P. P. Kuczynski and J. Williamson (eds.) After the Washington Consensus: Restarting Growth and Reform in Latin America, pp. 265-303, (Washington, D.C.: Institute for International Economics).

Rivers D. \& Rose, N. (1985) Passing the President's Program: Public Opinion and Presidential Influence in Congress, American Journal of Political Science, 29(2), pp. 183-96.

Shugart, M.S. \& Carey, J.M. (1992) Presidents and Assemblies: Constitutional Design and Electoral Dynamics, (New York: Cambridge University Press).

Siavelis, P. (2000) The President and Congress in Post-Authoritarian Chile: Institutional Constraints to Democratic Consolidation, (State College, PA: Pennsylvania State University Press).

Toro Maureira, S. (2007) Conducta Legislativa ante las Iniciativas del Ejecutivo: Unidad de los Bloques Políticos en Chile, Revista de Ciencia Política, 27: 1, pp. 23-41.

Wildavsky, A. (1966) The Two Presidencies, Trans-Action 4 (December), pp. 7-14.

Young, G. (1996) Committee Gatekeeping and Proposal Power under Single and Multiple Referral, Journal of Theoretical Politics, 8(1), pp. 65-78. 


\section{Notes}

${ }^{1}$ Exceptions include: Molinas, Pérez-Liñan \& Saiegh (2004); Cárdenas, Junguito \& Pachón (2006); and Calvo (2007).

${ }^{2}$ According to Carlos Carmona, director of the president’s Legislative Liaison Office (División JuridicoLegislativa, Minsterio Secretaria General de la Presidencia), simple urgencies assure that bills remain alive, 'given the scant time available in committee, bills without an urgency request are rarely seen.' Personal interview, Santiago, Chile, November 14, 2002.

${ }^{3}$ ibid.

${ }^{4}$ Data on Costa Rica provided by the Statistical Information Center of the Costa Rican Library of Congress (Biblioteca de la Asamblea Legislativa, Costa Rica). For Argentina see Molinelli, Palanza, \& $\operatorname{Sin}(1999)$.

${ }^{5}$ Wildavsky (1966) examined the fate of presidential initiatives between 1948 and 1964, finding that in the aggregate presidents prevail $70 \%$ of the time in foreign and defense policy matters, compared to only $40 \%$ for domestic initiatives.

${ }^{6}$ Approximately $15 \%$ of the initiatives introduced by Chilean presidents fall within the jurisdiction of this committee.

${ }^{7}$ Evidence from studies of party unity in Chile shows legislative parties behaving in a highly cohesive manner (Alemán \& Saiegh 2007; Carey 2002; Toro Maureira 2007).

${ }^{8}$ In deciding to measure this influence with a dummy variable capturing the first year in office, we followed the U.S. literature on presidential success (e.g., Lockerbie, Borrelli \& Hedger 1998; CanesWrone \& de Marchi 2002).

${ }^{9}$ We collected this data from the electronic archives of the Chilean Congress (Cámara de Diputados). For bills where online information was lacking, we collected information from the Library of Congress in Chile (Biblioteca del Congreso). 
${ }^{10}$ In these models, unexplained variation between groups and unexplained variation within groups have random variability.

${ }^{11}$ The data comes from polls conducted by Centro de Estudios Públicos, publicly available at http://www.cepchile.cl

${ }^{12}$ According to Article 17 of the internal rules of Congress, bills are 'archived' (i.e., killed) following two years without a committee report. Data on bills passed as of December 2007.

${ }^{13}$ We ran these models using STATA's (10.1) command xtmelogit. We checked our results using the Imer command in R 2.7.2 software, and found identical results.

${ }^{14}$ The coefficients that appear significant in Model \#1 are also significant in the fixed-effects model. These results are available from the authors upon request.

${ }^{15}$ This is the standard deviation of the estimated mean level of legislative success per congressional period (i.e., the intercept).

${ }^{16}$ Based on estimates for Model \#1 with other variables at their means.

${ }^{17}$ These predictions are for bills without urgencies that are not constitutional reforms.

${ }^{18}$ For incentives under the two-member electoral system see Magar, Rosenblum, \& Samuels (1998).

${ }^{19}$ The almost unanimous opposition to the use of urgencies by Chilean legislators is reflected in a series of interviews reported by Siavelis (2000, p. 152).

${ }^{20}$ Personal interview, Santiago, Chile, November 14, 2002. 